\title{
Impact of Access to Credit Facilities on Youth Economic Development: A Case of Mwanzo Youths in Uasin Gishu County, Kenya
}

\author{
Faith Kurgat., Kevin, O., Owembi \\ Student at the Catholic university of Eastern Africa GABA campus, Eldoret
}

Dr. Omwono Gedion Alang'o

Lecturer at L'ACADEMIER ARABE POUR SCIENCE DE FINANCEMENT ET DE BANCAIRE

\begin{abstract}
The purpose of this study was to find out the impact of access to credit facilities on youth economic development, specifically youths of Mwanzo estate in Uasin Gishu County. This study employed descriptive research design where information was collected both by interviewing and administering the questionnaires to a sample of individuals. The study targeted a population consisting of 415 youths with a sample size of 126 which represents $30 \%$ of the target population. Both qualitative and quantitative data was collected. Data was then summarized and coded systematically by use of Statistical Package for Social Science (SPSS). Findings on age of the respondents showed that majority of them were females $(55 \%)$ while male respondents were $45 \%$ and were in strong agreement with statements that access to credit facilities have improved the level of income, wealth, better jobs, and improved living standards. The study concluded that access to credit facilities was significant in predicting youth economic development and also recommended that credit facilities should be made accessible to youths in Mwanzo estate and in the whole country since they contribute positively towards poverty reduction, creation of employment, income generating and standards of living.
\end{abstract}

Keywords: access to credit facility, youth and economic development

\section{INTRODUCTION}

\section{Background of the Problem}

Credit Facility is an agreement with bank or other credit institutions that enables a person or organization to borrow money when it is needed. Types of credits may include loans, cash credit, overdraft and packing credit. SACCOs in Kenya are currently among the leading sources of the cooperative credit for socio-economic development for youths in Kenya (Alila\&Obado, 1990) asserted that Credit institutions such as Cooperatives in Kenya were started in 1908 and membership was limited to white colonial settlers. The first cooperative was established at Lumbwa, present day Kipkelion area. In 1944 colonial officers allowed Africans to form and join cooperatives as noted by (Gamba \& Komo, 2012). By 1950 most colonial civil servants began to support and encourage the development of cooperatives and by 1952, about 160 cooperatives had been registered (Alila \& Obado, 1990). After independence, most credit facilities had developed.

Youth is traditionally defined as a period of transition from childhood to adulthood. In the African Youth Report 2009 (UNECA 2009), youth are defined as people between 15 and 39 years of age. The National Youth Council Act of 2009 and the National Constitution of Kenya 2010 define youth as people aged between 18 and 34 years. However, several Kenyan communities define their youth population differently. For example, from Uasin Gishu County Integrated Development Plan 20132018, a youth has been defined as a person between the age of 15-29 years, and the population is expected to grow from 284,278 to 385,273 by 2017 . Skills development and Employment creation are therefore priority areas of investment for this group and this can be achieved if access to credit is being made easier for them. Poor access to credit by youths of Eldoret is a major constraint to the growth of youth development in Mwanzo estate in the County. Inadequate credit to finance their businesses and capital investment is a main cause of low youth development and productivity. The credit facilities offered by existing banks and the Agricultural Finance Corporation are not affordable due to the high interest rate charged. 
Faith Kurgat et al. "Impact of Access to Credit Facilities on Youth Economic Development: A Case of Mwanzo Youths in Uasin Gishu County"

(Andrew, 2005) elaborated that economic progress has been significantly advanced by pragmatic people including the youths who are entrepreneurial and innovative, able to exploit opportunities and willing to take risks. The role of the youth entrepreneurship by accessing credit in Kenya has often been underestimated. Over the years, however, it has become increasingly apparent that youths indeed contribute to economic development. Analyses of impacts of access to credits by youths in Kenya have included the impact of increased income levels. Namusonge (2006) stated that access to credit has eventually become a detrimental factor to advancing their livelihood as well as job creation. Crime, armed gangs and youths is a threat of militia and gangs is also real in Mwanzo area in Eldoret. Apart from the bulging numbers of unemployed youth easily getting persuaded to join these groups causing insecurity, there is a growing concern among the residents of the escalating rate of crime. These groups mostly will have an ethnic leaning and, in other cases political links. The mobilization of these groups, known for their criminal and violent activities; especially around election time is a strong issue.

Youth unemployment and underemployment continue to impose heavy social and economic costs and result in the loss of opportunities for economic growth in Uganda and Africa at large. A World Bank publication (2008/2009) notes that success in addressing youth unemployment in Africa will not be achieved and sustained through fragmented and isolated interventions. Instead, an arching guideline for addressing the youth employment challenge is the need for an integrated strategy for rural development, growth and job creation.

Youth are the foundation of a society (Goldin 2014). Their energy, inventiveness, character and orientation define the pace of development and the security of a nation. Through their creative talents and labor power, a nation makes giant strides in economic development and socio-political attainments. In their dreams and hopes, a nation founds her motivation; on their energies, she builds her vitality and purpose. And because of their dreams and aspirations, the future of a nation is assured. In Kenya, the government and other stakeholders have embarked on youth policies that might enhance their economic development. Thus, the policy endeavors to address issues affecting young people by providing broad-based strategies that can be used to give the youth meaningful opportunities to reach their maximum potential. It provides a broad framework within which all stakeholders, including the private and public sector.

The problem of unemployment has since then continued to occupy the minds of policy planners in both the Government and the private sector. The third National Development Plan in Kenya of 197478, while acknowledging the efforts made to address unemployment among the youth, warned that the problem would in future loom large. Efforts to initiate youth development programs have been made in other subsequent policy documents, such as Session Paper No. 2 of 1992 on Small Scale and Jua Kali Enterprises, the 1997-2001 Development Plan and the National Poverty Eradication Plan 19992015, among others. But despite these efforts, as well as an increase in the number of agencies dealing with the youth, problems affecting young people have continued to worsen. This situation has been attributed to the lack of a comprehensive policy to provide a blueprint for youth. Youth organizations have come up with innovative programs to address the youth's economic needs. However, some of the constraints have hampered their effectiveness in achieving their objectives which includes: Pressure from the high population growth resulting to pressure on the available resources, Lack of appropriate skills where youths are not properly equipped to possess life skills, Unclear and uncoordinated youth policies and programs, Resource Constraints where most of the youth programs, run by both the Government and non-governmental agencies lack adequate funds and equipment, which limits their success among others.

The Department of Youth Development undertakes various types of program to meet the current requirements of the unemployed youth population in Kenya. Micro credit program is one of them that play a vital role to create self-employment in different areas. The Department depending on various studies holds on idea that the marginal unemployed youths having credit facilities of the Department are being empowered and able to reduce their poverty by involving themselves in productive activities for socio economic development of the country as well (G.o.K)

Susan (2012) asserted that the chief executive officer of Youth Agenda says that given the low growth of employment in the formal sector, the growth of micro-enterprise provides the best opportunity for youth livelihood. Susan says the Youth Enterprise Development Fund which was meant to enhance youth participation in socio-economic development through the provision of credit to enable young 
Faith Kurgat et al. "Impact of Access to Credit Facilities on Youth Economic Development: A Case of Mwanzo Youths in Uasin Gishu County"

entrepreneurs to access finances to set up or expand business appears to be failing in this mandate. The fund has been dogged by technical, structural and governance challenges since inception and young people do not seem to be benefitting from it as banks and financial intermediaries exploit the interests to lend to their own clients. The procedures and interest charged for accessing the youth fund remain the two biggest hurdles to Youth Enterprise Development in Kenya.

According to Kiberenge (2013) the Uwezo fund launched by President Uhuru Kenyatta recently is the latest government bid to uplift women and youth through enterprise. Quick look at the past raises questions about thinking behind Uwezo and how different it will be from the previous ones that were marred by mismanagement and debts. The youth enterprise development fund and the women's economic empowerment funds that have been lending to their target groups for the past six years have little to show for it. The two have little impact despite receiving a combined total of ksh.12.5 billion to date.It is feared that haste in Uwezo fund without proper research as well as overlaps with the existing funds could jeopardize it like the defunct Kazi Kwa Vijana which initially was a world bank sponsored project but cancelled in 2011 in amid claims of misappropriation. Critics see this as reactive political gift haphazardly thrust to entice the youth and women exposing them to the abuse by unscrupulous managers.

Youth poverty requires special attention (UNECA 2002). Young people experience particular vulnerabilities that make them prone to suffering from poverty, unemployment, poor living standards among others. Through investing in young people, it is possible to embark on the demographic transition by lowering population growth; and by improving the situation of youth, countries can decrease the chance that they will later become involved in criminal activity and civil conflict.

Given the right combination of motivation, ideas and opportunities, youth are more than able to establish productive and creative businesses (Chigunta 2005). Engaging in entrepreneurship shifts young people from being "job seekers" to "job creators," and also from social dependence to selfsufficiency. Many self-employed youth also contribute to the upkeep of their family, sometimes in a leading role in the absence of parents. Despite these potential benefits of entrepreneurship, the majority of youth continue to look up to the state for employment rather than creating their own jobs and employing others. Different stakeholders, including scholars, civil society organizations and policy makers have identified entrepreneurship as a tool for improving livelihoods of youths in Africa (Chigunta, Schnurr, James-Wilson \&Torres, 2005; Youth Business International, 2011; International Labor Organization, 2005). It is widely believed that entrepreneurship promises jobs to the youth (Curtain, 2000); provides valuable goods and services to society (OECD, 2001d); and promotes innovation and resilience (White \& Kenyon, 2000). Because youths are more likely than adults to be unemployed, entrepreneurship gives them livelihood alternatives, economic independence, and a positive socio-psychology which will integrate them into the mainstream economy (Schoof, 2006; Chingunta, 2002). This can only be achieved if credit facilities can only be accessed easily by the youth which will finally enhance their economic development.

\section{Statement of the Problem}

Ideally, Microfinancing banks also need to come forward to facilitate young entrepreneurs' initiatives to set up new businesses by offering venture capital and also project incubating facility on partnership basis. In such cases after operation of a project starts and funds are generated, the financing bank/ microfinancial institutions can transfer its share of ownership to the client by providing finance to the client equivalent to investment made by the bank for the project. Through this service financing, bank can earn technical assistance and management fee also in addition to mark up on the finance provided.

Unfortunately, in Mwanza, microfinancial institutions have avoided lending to youth due to their relative inability to comply with the high transaction costs, difficulty in assessing and managing their risk profile, and lack of the required financial documentation as well as collateral.

Studies have shown that access to credit facilities by low income population segments such as youth can improve their income and therefore their welfare and living standards. In a study done by Karanja, N,P., et al (2016) on effect to access on growth of youth owned micro and small enterprises in Kenya, found that majority of youth owned MSEs faced challenges in accessing capital, due to the high cost 
Faith Kurgat et al. "Impact of Access to Credit Facilities on Youth Economic Development: A Case of Mwanzo Youths in Uasin Gishu County"

of finance, high rates of interest, the high cost of accessing capital due to high cost of finance, high rate of interests, high cost of accessing credit and collateral challenges. In yet another study by Chebet,D,C (2013) on effects of access to financial credit on growth of women owned small retail entrprises in Uasin Gishu County: A case of Kapseret Constituency, Kenya, established that, culture, educational level, interest rates affects women entrepreneurs and this finally affect their economic growth. However in a study by Wanjiku, E,.\& N A (2016) on influence of microfinancial services on economic empowerment of women on Olkalou Constituency, Kenya found that, microfinancial services provided financial access which provide women with capital, training, savings leading to women engaugement in income generating activities with a positive outcome on women empowerment in the sociaty. This study therefore, examines the impact of accessing to credit facilities on youth economic development: a case of Mwanzo youth in Uasin Gishu County, Kenya

\section{Research Questions}

The following research questions guided the study

i. What are the impacts of access to credit facilities on incomes of the youth in Mwanzo estate in Eldoret?

ii. How has access to credit facilities impacted on standard of living among the youths of Mwanzo in Eldoret?

iii. To what level has access to credit facilities impacted on employment opportunities on youths in Mwanzo estate in Eldoret?

iv. What are the impacts of access to credit facilities on poverty on youths in Mwanzo estate in Eldoret?

\section{Significance of the Study}

The purpose of the study was to find out the impacts of access to credit facilities on youth economic development in Mwanzo Estate in Eldoret. This study was deemed significant because the youths of the area will benefit as the credit accessed will help finance their businesses and projects hence leading to youth's economic development. The youths from Mwanzo Estate in Eldoret were the beneficiary of these study findings since they understood better the impact of accessing credit facilities for their economic development. The government of Uasin Gishu County also benefited from these study findings in order to know measures to put in place to help youth's access credit facilities for their economic development and to achieve the objectives that have not been realized. Non-Governmental Organizations also benefited from these findings as they were be able to know the status of the livelihood of the youths of Mwanzo Estate in terms of living standards, income, employment level and poverty level in order to know how they can empower them. This study was also be relevant to other researchers who gained more understanding on impact of credit facilities on youth economic development and also in reviewing their literature.

\section{Theoretical Framework}

\section{The Rostow's Stages of Growth model}

The model postulates that economic growth occurs in five basic stages, of varying length (Traditional society, Pre-conditions to "take-off", Take off Drive to maturity, Drive to maturity and age of mass consumption).

Rostow (1960) asserts that countries go through each of these stages fairly linearly, and set out a number of conditions that were likely to occur in investment, consumption and social trends at each state. Not all of the conditions were certain to occur at each stage, however, and the stages and transition periods may occur at varying lengths from country to country, and even from region to region. Thus, when a segment of a population such as youths succeeds in going through these stages, there will be a positive impact on their livelihoods resulting to improved living standards, poverty reduction and improved income levels as well as employment levels. 
Faith Kurgat et al. "Impact of Access to Credit Facilities on Youth Economic Development: A Case of Mwanzo Youths in Uasin Gishu County"

\section{Conceptual Framework}

\section{INDEPENDENT VARIABLES}

\begin{tabular}{|c||ll|}
\hline Credits facilities & \multicolumn{2}{l|}{ Youth Economic Development } \\
i. Loan & i. & Income \\
ii. Overdraft & ii. & Standard of Living \\
iii. Cash Credit & iii. & Employment \\
iv. Packing Credit & iv. & Poverty \\
\hline
\end{tabular}

Figure1.1. Conceptual framework

SOURCE: (Researcher, 2015)

\section{LITERATURE REVIEW}

\section{The Dual-sector model}

In the model, the traditional agricultural sector is typically characterized by low wages, an abundance of labour, and low productivity through a labour intensive production process. In contrast, the modern manufacturing sector is defined by higher wage rates than the agricultural sector, higher marginal productivity, and a demand for more workers initially. Also, the manufacturing sector is assumed to use a production process that is capital intensive, so investment and capital formation in the manufacturing sector are possible over time as capitalists' profits are reinvested in the capital stock. Thus this theory is relevant to the study since it's a theory of development which is in line with my studies since it's focusing on youth economic development that can be achieved through labor transition from agricultural sector to the modern industrial sector.

\section{The Credit Theory of Money}

When we are successful in business, we accumulate credits on a banker and we can then buy without creating new debts, by merely transferring to our sellers a part of our accumulated credits. Thus this theory was deemed relevant since it explain how credit is circulating in the economy from suppliers to creditors and to banks who lend out credit facilities to its customers.

\section{Dependency Theory}

It holds the view that poverty is externally created and can only be eradicated if the developed world alters the unfavorable trade relations with the developing countries. The phenomenon was that poor countries exported primary commodities to the rich countries and then manufactured products out of those commodities and sold them back to the poorer countries. The "Value Added" by manufacturing a usable product always cost more than the primary products used to create those products. Therefore, poorer countries would never be earning enough from their export earnings to pay for their imports. The poorer countries would still sell their primary products on the world market, but their foreign exchange reserves would not be used to purchase their manufactures from abroad. The theory is relevant since it's a theory of development and shows how poverty is created externally and how it can be eradicated.

\section{In-Kind Finance: A Theory of Trade Credit}

When trade credit is more expensive, the puzzle is that banks are unwilling to lend. In the course of business, suppliers obtain information about the borrower which other lenders can only obtain at a cost. The theory is relevant since it shows that aggregate investment is higher when trade credit is available because trade credit allows medium- and low-wealth firms to invest more than their bank credit constraints would otherwise permit.

\section{Critics of the Theories}

The transfer of unskilled workers from agriculture to industry is regarded as almost smooth and costless, but this does not occur in practice because industry requires different types of labor. The problem can be solved by investment in education and skill formation, but the process is neither 
Faith Kurgat et al. "Impact of Access to Credit Facilities on Youth Economic Development: A Case of Mwanzo Youths in Uasin Gishu County"

smooth nor inexpensive. The model assumes rationality, perfect information and unlimited capital formation in industry. These do not exist in practical situations and so the full extent of the model is rarely realized. However, the model does provide a good general theory on labour transitioning in developing economies.

In Dependency theory, three issues made this theory difficult to follow. The first is that the internal markets of the poorer countries were not large enough to support the economies of scale used by the richer countries to keep their prices low. The second issue concerned the political will of the poorer countries as to whether a transformation from being primary products producers was possible or desirable. The final issue revolved around the extent to which the poorer countries actually had control of their primary products, particularly in the area of selling those products abroad. At this point dependency theory was viewed as a possible way of explaining the persistent poverty of the poorer countries. Thus the theory was deemed valid as in line with the current situation affecting African nations including Kenya. Suppliers not only sell goods and services, but extend large amounts of credit as well.

\section{Critical review of Empirical Studies}

Ansoglenang (2006) carried out a study on Rural Women and Micro-credit schemes. The essence of these credit schemes as stated by the researcher was to help the rural poor, especially women, earn a decent living through their on-going income generating activities (IGA). The study emphasized that rural women play an important role in the provision of domestic welfare. The researcher collected data through the use of open-ended semi-structured interview guide, focus group discussion, direct observation and informal discussions. The purpose of these techniques was to allow probing to ascertain the impact of the micro-credits to poverty reduction in the study area. It was realized that women have assumed certain household responsibilities, which were formerly men's gender roles, such as providing money and other material resources for house keepings. The researcher made the following recommendation towards the empowerment of women: an appreciable increase in the loans, prioritizing girl-child education, developing and encouraging the use of appropriate technology, and engendering the loan scheme or helping rural women side-by-side their men folk.

Lagat (2009) conducted a research on effect of credit on household welfare: the case of "village Bank" model in Bomet District, Kenya. The purpose of the study was to assess the role of credit service on welfare of the microfinance clients. It was also to enable the microfinance institutions assess if they are achieving the intended objectives of their program". A sample of 125 "village bank" members was selected, out of which 91 had used the credit service and the other 34 had not. Primary data on the selected respondents were collected using a structured interview schedule and secondary data were obtained from the selected "village banks" operating in the study area and relevant government departments in the district. The results from the study indicated that farm income, offfarm income, distance to market and household assets influences the probability to participate in "village bank" credit. The household income of credit participants was also higher than that of the non-participants. There was a positive relationship between the amount borrowed and household expenditure. Age of the household head, farm income; distance to market and off-farm income also plaid a significant role in influencing the wellbeing of a household.

Siakwa (2010) carried out a study of microcredit as a strategy for poverty reduction, youth and women empowerment in Ghana. The study explores the efficiency of microcredit as a strategy for poverty reduction especially among women. Guided by a notion that the poor are not passive but could be active agents of change, the researcher used credit investment model to explain how microcredit could help transform the vicious cycle of poverty into a virtuous cycles. Thus, in certain cases, the aim is to use microcredit as a way of responding quickly to the vulnerabilities of surplus labor in growing informal sectors during and after adjustment process. Nevertheless, based on the experiences of the beneficiaries, the researcher found out that the impact of microcredit has been mixed. Certain beneficiaries are successful, others partially successful and some have failed to use the loans to improve their lives. Though microcredit has its challenges, it can be noted that when the right mechanisms and structure are put in place and implemented vigilantly, it could serve as a catalyst to get people out of poverty. Yet, it is prudent to view microcredit as a means to an end and not an end in itself 
Faith Kurgat et al. "Impact of Access to Credit Facilities on Youth Economic Development: A Case of Mwanzo Youths in Uasin Gishu County"

Zachary (2013) conducted a research on effects of interest rates on demand for credit by small and medium enterprises in Nairobi County. The researcher in her study sought to evaluate the effect of interest rates on demand for loans by SMEs in Nairobi County. To achieve this objective, the researcher employed a correlation research design. Data was collected using a semi-structured questionnaire from SMEs in Nairobi County. The researcher adopted a drop-and -pick-later approach where questionnaires were issued in the morning and picked in the evening to allow the respondents to complete the questionnaires. Both descriptive and inferential statistics were used. The research findings revealed that there was a very strong positive relationship between demand for credit, interest rate, annual profit and owner's equity. The study also revealed that $86.9 \%$ of demand for credit by SMEs in Nairobi County could be explained by interest rates. From this study it was evident that at 95\% confidence level, the variables produced statistically significant values and can be relied on to explain demand for loans by SMEs from lending institutions. The findings further revealed that effective interest rates, annual profits and owner's equity explained demand for loans in that order. The research findings were farmers presented in pie charts, bar graphs, and tables for clarity. The findings of this study will be of great use to the government, lending institutions in formulating credit policies so as to promote the uptake of credit facilities in Kenya.

Poliquit (2006) carried out a study on accessibility of credit of rural farmers in Philippines. The aim was to explore and understand the perceptions of small farmers towards rural credit and to collect information in proposing appropriate credit system for them. The study used interview method and qualitative data collection. The study found out that access to credit by farmers was limited to the available credit services in the research area and therefore farmers choices and preferences were not well served. The study recommended that accessibility to small farmers could be improved by providing innovative financing schemes that addresses problems of farmers who lack collateral.

\section{Knowledge Gap}

Despite the fact that many scholar Burkhart and Ellingsen, Innes, Sir Lewis and Restow have carried out research on credit and economic development, many of these studies have focused on stages of economic growth, money as a means of exchange, trade credit and bank finance but not on the four indicators of economic development discussed in this study. These include: poverty, income, employment opportunities and poverty. Therefore, this study seeks to investigate the impact of access to credit facilities and how this has affected the economic development of youth in Mwanzo Estate, in Uasin Gishu County of Kenya.

\section{RESEARCH DESIGN AND METHODOLOGY}

\section{Research Design}

This study adopted survey research design. This method is viewed suitable and adequate as it collects information about attitudes, opinions and socio economic issues.

\section{Target Population}

The target population was youths of Eldoret town specifically Mwanzo Estate. These comprised of 150 beneficiaries of loan facilities, 95 beneficiaries of overdraft, 120 beneficiaries of cash credit and 60 beneficiaries of packing credit. These beneficiaries were obtained from bank records and county government records.

\section{Description of the Sample and Sampling Procedure}

The researcher employed simple random sampling to pick four credit facilities. Out of 420 youths selected who have benefited on credit facilities, a representative study sample of 126 respondents is selected using simple random sampling.

Table3.1. Sample Size Determination

\begin{tabular}{|l|l|l|}
\hline Credit Facilities & Target Population & Sample Size (30\%) \\
\hline Loans & 150 & 45 \\
\hline Overdraft & 95 & 29 \\
\hline Cash Credit & 120 & 36 \\
\hline Packing Credit & 60 & 18 \\
\hline Total & $\mathbf{4 2 5}$ & $\mathbf{1 2 8}$ \\
\hline
\end{tabular}

(Source: County Government of Uasin Gishu County) 
Faith Kurgat et al. "Impact of Access to Credit Facilities on Youth Economic Development: A Case of Mwanzo Youths in Uasin Gishu County"

\section{Description of Research Instruments}

Closed and open ended questionnaires were the main data collection instrument. The instrument was divided into two sections, section A has demographic information and section B has research questions. Interview guides were also used to seek clarification through probing. Secondary data were also drawn from already published sources such as documentaries from local authorities like County offices

\section{Description of Data Analysis Procedures}

Data was analysed with two analysis techniques namely; descriptive analysis and inferential statistics. Descriptive analysis is the elementary transformation of data in a way that describes the basic characteristics such as central tendency, distribution, and variability. Once the descriptive analysis was done, the information was presented through various ways such as tabular format, frequency tables and frequency distribution tables (Statistical Package for Social Sciences (SPSS) was used as a tool in analysis.

\section{DISCUSSIONS}

\section{Response Rate}

The preliminary section of this study was done by administering a questionnaire. Out of the 128 targeted respondents, all were accessed by the researcher. Thus, the study showed that respondent turnout was $100 \%$. This implies that the response rate indicated for this study is very good for analysis and reporting.

\section{Demographic Information}

The demographic information of the respondents is considered very crucial not only for subsequent discussions of the findings but also for the authenticity and generalization of the results. This section, therefore, presents respondents' background information considered crucial for discussions in this study such as gender, age, marital Status, highest level of education and types of credit facilities involved in.

\section{Gender}

Findings on age of the respondents showed that majority of the respondents $55 \%$ were female respondents while male respondents were $45 \%$.

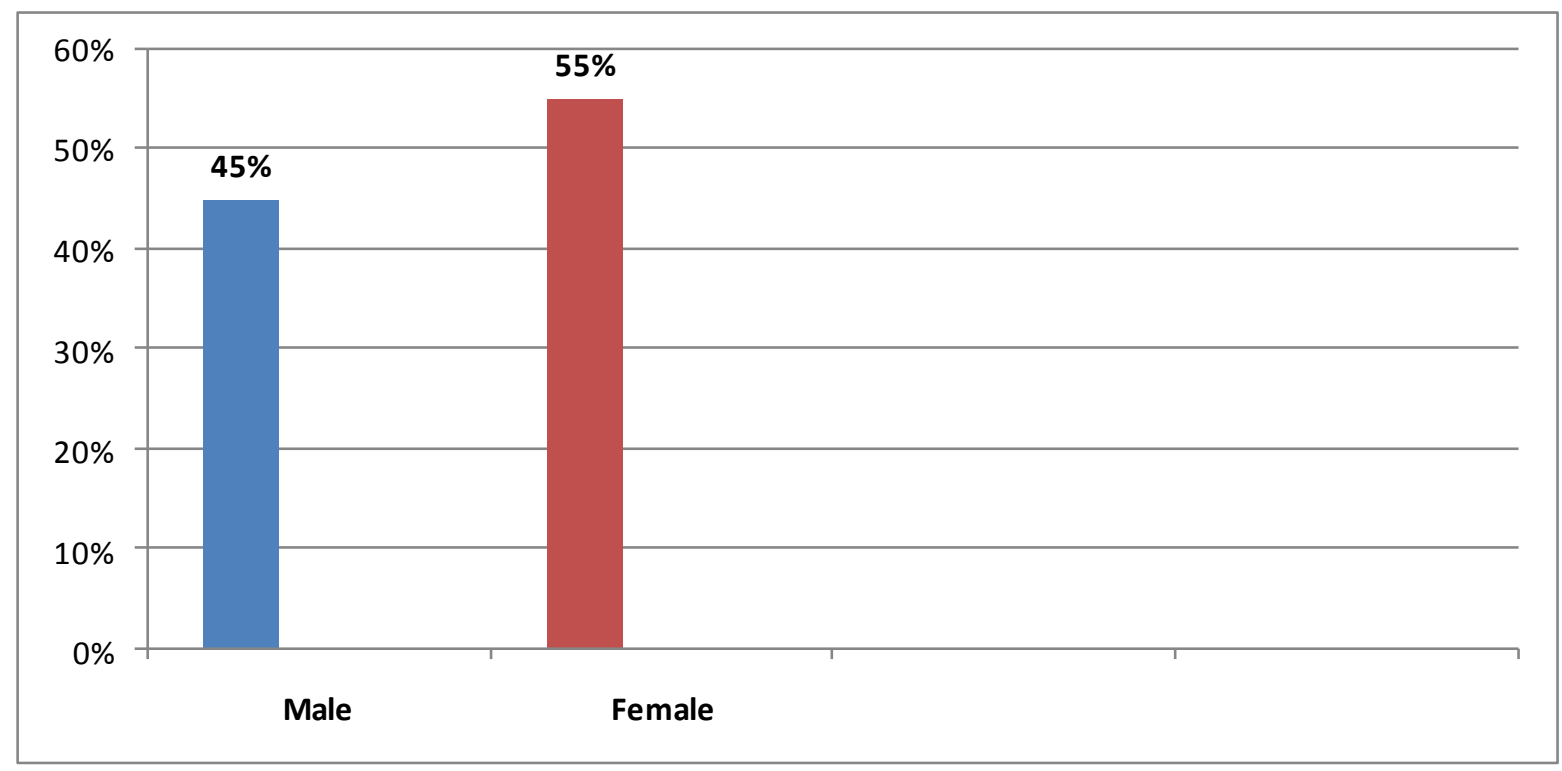

Fig4.1. Gender

Age

Findings on age showed that majority of the respondents $45 \%$ were in the age bracket of 20-25 years, $35 \%$ were in the age bracket of 26-30 years, the rest, $10 \%$ each were in the age brackets of 15-20 and 30-35 years. 
Faith Kurgat et al. "Impact of Access to Credit Facilities on Youth Economic Development: A Case of Mwanzo Youths in Uasin Gishu County"

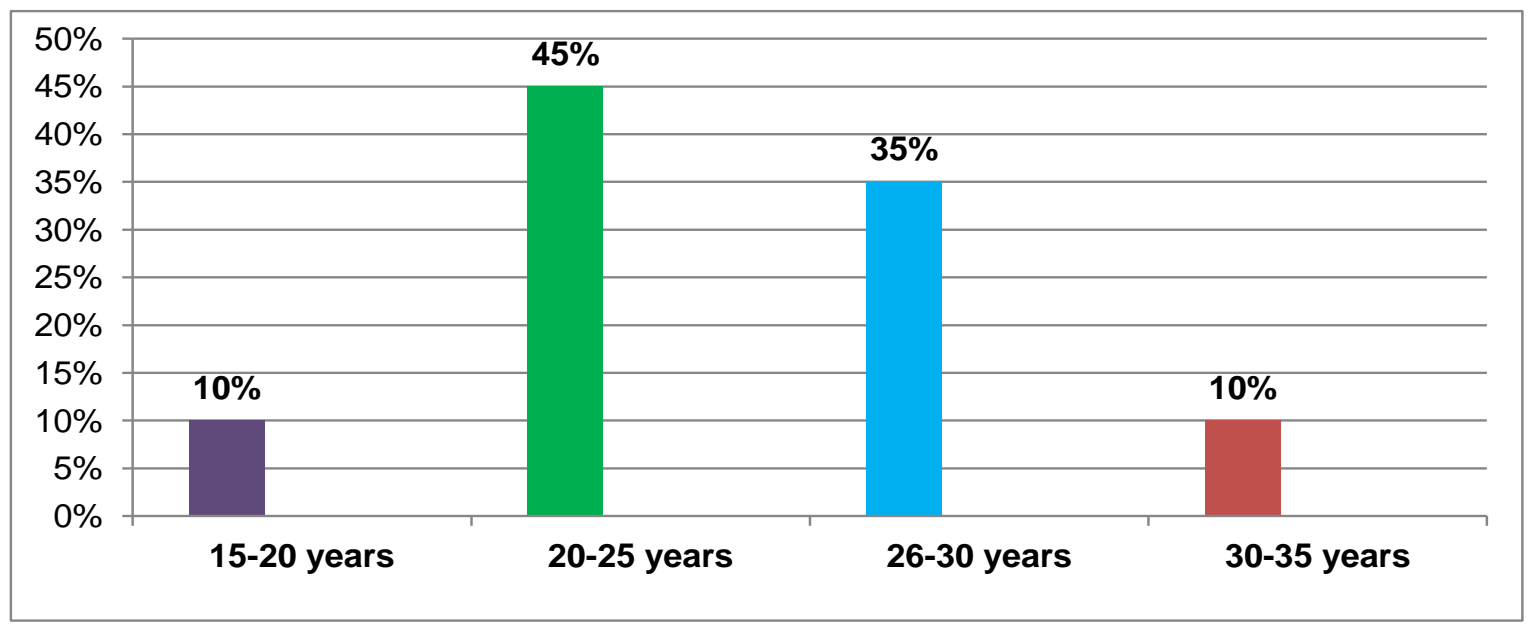

Fig4.2. Age

\section{Marital Status}

Findings on marital status showed that majority of the respondents $75 \%$ were single, $20 \%$ were married while $5 \%$ were divorced or separated.

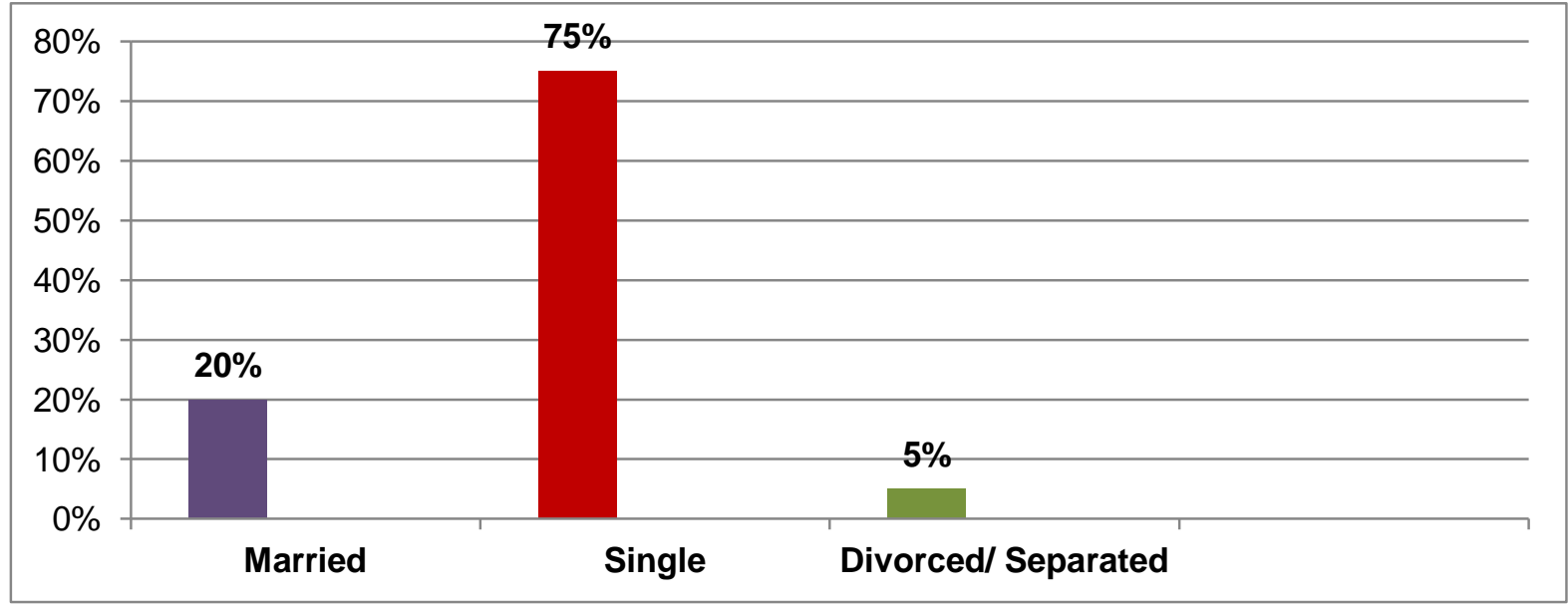

Fig4.3. Marital Status

Findings on educational level showed that majority $45 \%$ had secondary education, $25 \%$ had college education while primary and university education had been attained by $15 \%$ each.

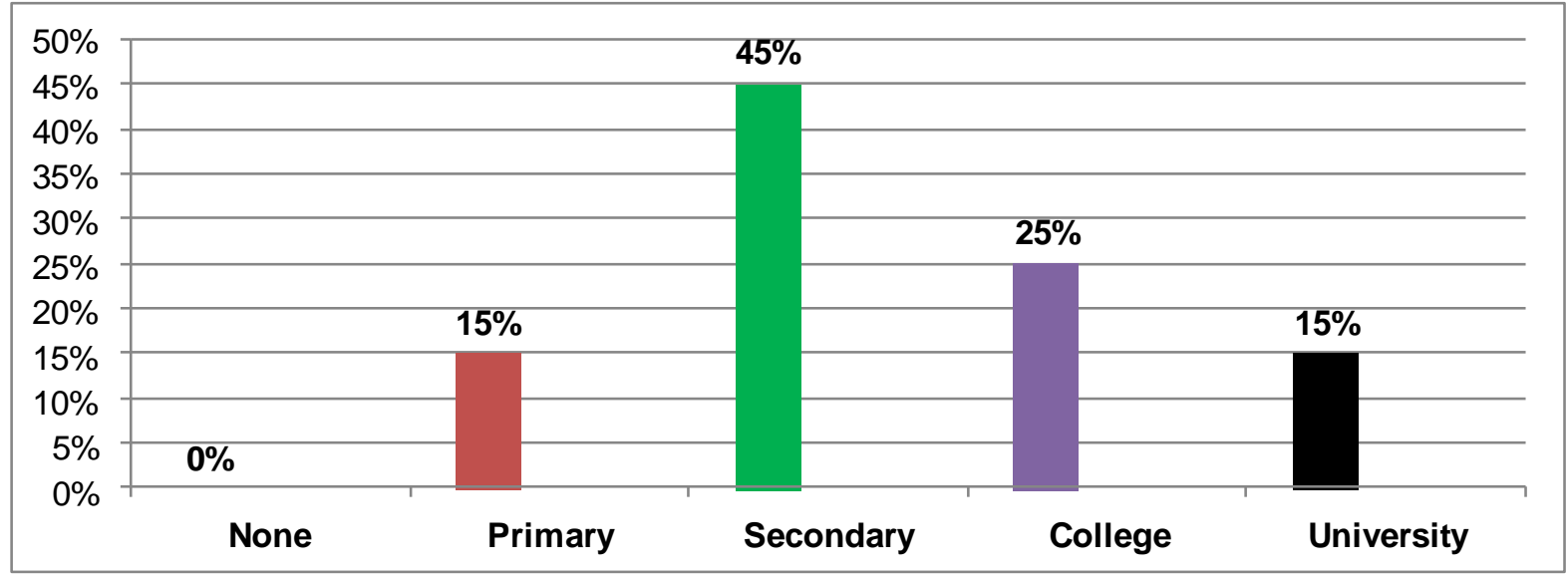

Figure4.4. Highest level of Education

\section{Types of Credit Facilities Involved In}

Majority of the respondents had accessed loans as shown by $88 \% .5 \%$ had accessed cash credit, $4 \%$ had accessed overdraft while $3 \%$ had accessed packing credit. 
Faith Kurgat et al. "Impact of Access to Credit Facilities on Youth Economic Development: A Case of Mwanzo Youths in Uasin Gishu County"

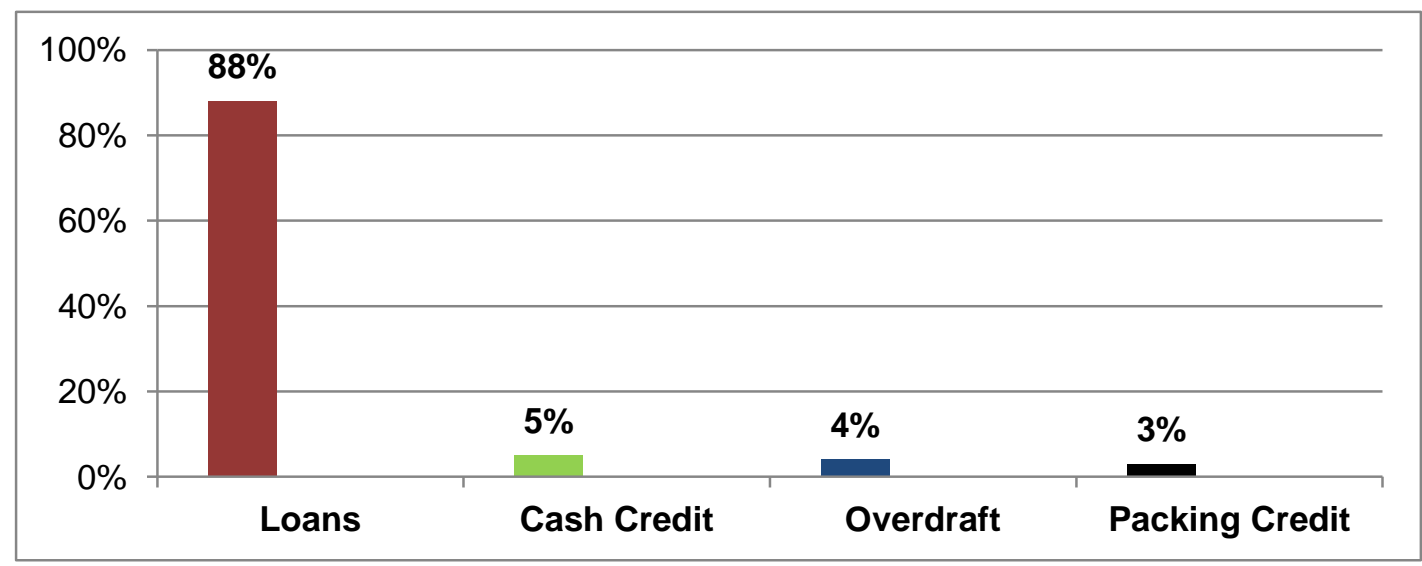

Fig4.5. Types of credit facilities involved in

Contribution of Credit Facilities on the Level of Income

Respondents were asked to rate the statement that sought to determine the contribution of credit facilities on the level of income among the youth. A five point likert scale was used where $1=$ strongly disagree, $2=$ Disagree, $3=$ Not sure, $4=$ Agree $5=$ Strongly Agree. The results were summarized as in table 4.1.

Table4.1. Contribution of Credit Facilities on the level of income

\begin{tabular}{|l|l|l|}
\hline Statements on level of income & Mean & Std. Deviation \\
\hline Access to credit facilities have improved the level of income & 4.13 & 0.55 \\
\hline Access to credit facilities have enabled the youths meet their daily basic needs & 3.37 & 0.79 \\
\hline Access to credit facilities have enabled Mwanzo youths to save more & 3.41 & 0.72 \\
\hline Access to credit facilities have led to youths making investments & 3.76 & 0.65 \\
\hline $\begin{array}{l}\text { Access to credit facilities have empowered youths of Mwanzo to own assets and } \\
\text { property }\end{array}$ & 3.41 & 0.85 \\
\hline
\end{tabular}

Findings showed that, respondents were in strong agreement with the statement; access to credit facilities has improved the level of income among the youth as shown by a mean of 4.13 and a standard deviation of 0.55. Regarding other statements, the mean ranged between 3.37-3.76 implying that respondents were generally in agreement with these statements.

\section{Impact of Access to Credit Facilities on Standard of Living}

Respondents were asked to rate the statement that sought to determine the Impact of access to credit facilities on standard of livingamong the youth. A five point likert scale was used where $1=$ Strongly Disagree, $2=$ Disagree, $3=$ Not sure, $4=$ Agree 5= Strongly Agree. The results were summarized as in table 4.2.

\begin{tabular}{|l|l|l|}
\hline Statements on standard of living & Mean & Std. Deviation \\
\hline Quality of life of youths in Mwanzo has improved after accessing credit facilities & 3.54 & 0.82 \\
\hline The level of wealth has increased after accessing credit & 4.2 & 0.63 \\
\hline $\begin{array}{l}\text { There has been access to new technological tools and instruments that have } \\
\text { improved standard of living of youths }\end{array}$ & 3.19 & 1.05 \\
\hline Youths no longer have to work for many hours before purchasing necessities & 3.65 & 0.85 \\
\hline Socioeconomic class of youths in Mwanzo has improved from lower to middle & 3.83 & 0.8 \\
\hline
\end{tabular}

From the findings, the study established that, majority of the respondents were in strong agreement that the level of wealth among the youth has increased after accessing credit as per the mean value of 4.2 and standard deviation of 0.63. Regarding other statements, the mean ranged between 3.19-3.83 implying that respondents were generally in agreement with the statements.

\section{Impact of Access to Credit Facilities on Employment}

Respondents were asked to rate the statement that sought to determine the Impact of access to credit facilities on employment among the youth. A five point likert scale was used where $1=$ strongly disagree, $2=$ Disagree, $3=$ Not sure, $4=$ Agree $5=$ Strongly Agree. The results were summarized as in table 4.3. 
Faith Kurgat et al. "Impact of Access to Credit Facilities on Youth Economic Development: A Case of Mwanzo Youths in Uasin Gishu County"

\begin{tabular}{|l|l|l|}
\hline Statements on employment opportunities & Mean & Std. Deviation \\
\hline Youths have accessed better job opportunities than before & 4.31 & 1.01 \\
\hline Access to credit facilities has led to job creation for youths & 4.15 & 0.89 \\
\hline Employed youths have employed other youths & 4.48 & 0.62 \\
\hline Credit facilities have reduced crimes as unemployed youths avoid idling & 3.92 & 1.12 \\
\hline $\begin{array}{l}\text { Youths of Mwanzo have equal opportunities to be self employed without } \\
\text { discrimination }\end{array}$ & 3.49 & 0.97 \\
\hline
\end{tabular}

Findings showed that, respondents were in strong agreement with the statements; youths have accessed better job opportunities than before, access to credit facilities has led to job creation for youths and employed youths have employed other youths as per the mean values; $4.31(\mathrm{SD}=1.01)$, $4.15(\mathrm{SD}=0.89)$ and $4.48(\mathrm{SD}=0.62)$ respectively. Regarding other statements, respondents were generally in agreement as per the mean values of $3.92(\mathrm{SD}=1.12)$ and $3.49(\mathrm{SD}=0.97)$ respectively.

\section{Impact of Access to Credit Facilities on Poverty Reduction}

Respondents were asked to rate the statement that sought to determine the Impact of access to credit facilities on poverty reduction. A five point likert scale was used where $1=$ Strongly disagree, $2=$ Disagree, $3=$ Not sure, 4= Agree 5= Strongly Agree. The results were summarized as in table 4.4.

\begin{tabular}{|l|l|l|}
\hline Statements on poverty & Mean & Std. Deviation \\
\hline Malnutrition, hunger diseases have reduced & 4 & 0.81 \\
\hline Youths are now enjoying improved living standards & 4.13 & 0.56 \\
\hline Increased output has enabled hunger eradication & 3.51 & 0.84 \\
\hline $\begin{array}{l}\text { Employed youths have educated their siblings hence reducing poverty in later } \\
\text { days }\end{array}$ & 3.13 & 1.07 \\
\hline
\end{tabular}

Findings showed that, respondents were in strong agreement with the statement that youths are now enjoying improved living standards due to credit access as per the mean value of $4.13(\mathrm{SD}=0.56)$. Regarding other statements, the study established that respondents were in agreement since the mean response ranged between 3.13-4.

\section{RESULTS}

\section{Demographic Information}

Findings on age of the respondents showed that majority of the respondents $55 \%$ were female respondents while male respondents were 45\%. Findings on age showed that majority of the respondents $45 \%$ were in the age bracket of 20-25 years, 35\% were in the age bracket of 26-30 years, the rest, $10 \%$ each were in the age brackets of 15-20 and 30-35 years. Findings on marital status showed that majority of the respondents $75 \%$ were single, $20 \%$ were married while $5 \%$ were divorced or separated. Findings on educational level showed that majority $45 \%$ had secondary education, $25 \%$ had college education while primary and university education had been attained by $15 \%$ each. Majority of the respondents had accessed loans as shown by $88 \% .5 \%$ had accessed cash credit, $4 \%$ had accessed overdraft while $3 \%$ had accessed packing credit.

\section{Contribution of Credit Facilities on the Level of Income}

Findings showed that, respondents were in strong agreement with the statement; access to credit facilities has improved the level of income among the youth as shown by a mean of 4.13 and a standard deviation of 0.55. Regarding other statements, the mean ranged between 3.37-3.76 implying that respondents were generally in agreement with these statements.

\section{Impact of Access to Credit Facilities on Standard of Living}

From the findings, the study established that, majority of the respondents were in strong agreement that the level of wealth among the youth has increased after accessing credit as per the mean value of 4.2 and standard deviation of 0.63. Regarding other statements, the mean ranged between 3.19-3.83 implying that respondents were generally in agreement with the statements.

\section{Impact of Access to Credit Facilities on Employment}

Findings showed that, respondents were in strong agreement with the statements; youths have accessed better job opportunities than before, access to credit facilities has led to job creation for youths and employed youths have employed other youths as per the mean values; $4.31(\mathrm{SD}=1.01)$, 
Faith Kurgat et al. "Impact of Access to Credit Facilities on Youth Economic Development: A Case of Mwanzo Youths in Uasin Gishu County"

4.15( $\mathrm{SD}=0.89)$ and $4.48(\mathrm{SD}=0.62)$ respectively. Regarding other statements, respondents were generally in agreement as per the mean values of $3.92(\mathrm{SD}=1.12)$ and $3.49(\mathrm{SD}=0.97)$ respectively.

Impact of Access to Credit Facilities on Poverty Reduction

Findings showed that, respondents were in strong agreement with the statement that youths are now enjoying improved living standards due to credit access as per the mean value of $4.13(\mathrm{SD}=0.56)$. Regarding other statements, the study established that respondents were in agreement since the mean response ranged between 3. 13-4.

\section{CONCLUSION}

The study concluded that access to credit facilities was significant in predicting youth economic development as per the regression results $\left(R^{2}=0.525\right)$.

\section{RECOMMENDATION}

The study recommended that Credit facilities should be made accessible to youths country wide since they contribute positively towards poverty reduction, creation of employment, income generation and standard of living.

\section{SUGGESTIONS FOR FURTHER STUDIES}

Other researchers should consider conducting a similar a study in other areas of the country to ascertain the consistency of the results.

\section{REFFERENCES}

Ansoglenang, G (2006). Rural Women and Micro-Credit Schemes: unpublished journal at the Faculty of Social Science, University of Tromso

Beck, et al (2007), Finance inequality and the poor. Journal of the economic growth.

Burkart, M. \&Tore, E. (2004) "In-Kind Finance." Centre for Economic and Policy Research Working Paper No. 3536, 2002

Cole A.R, Mehran, H (2009): Gender and the availability of credit to privately held firms: Evidence from the survey of small business finances.

Chebet, Dorine Cheluge (2013) effects of access to financial credit on growth of women owned small retail entrprises in Uasin Gishu County: A case of Kapseret Constituency, Kenya, and unpublished journal from University of Nairobi Library Nairobi Kenya.

Ferraro, V (2008) "Dependency Theory: An Introduction," In The Development Economics Reader, ed. Giorgio Secondi (London: Routledge, 2008), pp. 58-64

Gamba. P \& Komo,I. (2011). Evolution, growth and decline of co-operative sector, a prepared for the center for governace and development.

Lagat, K.J (2009). Effects of credit on household welfare: The case of 'Village Bank' Model in Bomet District, Kenya. Unpublished journal at Egerton University library, Nakuru

Kenya.

Karanja, Patrick Ngugi, kanali Christopher, kagiri Assamptah \& Mugambi Peter Kimuru, (2016), effect to access on growth of youth owned micro and small enterprises in Kenya. Journal published by international journal of advanced Research in Management and social sciences ISSN 22786236. Impact factor 6.284 Vol. 5 | No. 4 | April 2016 www.garph.co.uk IJARMSS | 252

Ministry of Planning and National Development 2006-2010) Seventh National Development plan: Creating New Opportunities.

Mitchell-Innes, Alfred (1914). "The Credit Theory of Money, "The Banking Law Journal.

Obado, P.O, \& AlilaP.O (1990) Co-operative Credit: The Kenyan Saccos in s historical and Development perspective

Poliquit, L. y. (2016) Accessibility of Rural Credit to Farmers in the Philipines: A thesis for Rostow, W. W. (1960). The Stages of Economic Growth: A Non-Communist Manifesto, Cambridge University Press. 
Faith Kurgat et al. "Impact of Access to Credit Facilities on Youth Economic Development: A Case of Mwanzo Youths in Uasin Gishu County"

Siakwa. P(2010). 'Micro-credit as a strategy for Poverty Reduction, Youth and Women Empowerment, Ghana'. Unpublished journal at the library of University of Oslo.

United Nations Economic Commission for Africa (UNECA) (2002) "Youth and Employment in Africa", Paper prepared for and presented at the Youth Employment Summit, Alexandria, Egypt.

United Nations Economic Commission for Africa (UNECA) (2002) "Youth and Employment in Africa", Paper prepared for and presented at the Youth Employment Summit, Alexandria, Egypt, September.

Wanjiku, Elizabeth,. \& Njiru Alex (2016) ' influence of microfinancial services on economic Empowerment of women on Olkalou Constituency, Kenya'. Journal published by International journal of research in Business Management (IJRBM) ISSN (E): 2321- 886X; ISSN (P): 23474572

Wanjohi, A. \& Mugure, A. (2008). "Factors affecting the growth of MSEs in rural areas of Kenya", A case of ICT firms in Kiserian Township, Kajiado District of Kenya

Zachary. N. L, (2013). 'The effect of Interest Rates on Demand for Credit by Small Medium Enterprises in Nairobi County'

\section{AUTHORS BIOGRAPHY}

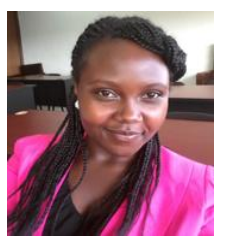

Faith Kurgat, was born in $17^{\text {th }}$ march 1993 a single. She holds Bachelor of Commerce in Finance from the catholic University of Eastern Africa, GABA campus Eldoret. Currently she works at Heritage insurance company limited as business development officer in Eldoret Area.

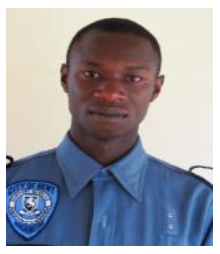

Kevin O. Owembi, holds a degree in Bachelor Of Commerce (Finance Option) and a master degree In Business Administration(MBA) Financial management from the Catholic University of Eastern Africa, Eldoret he has an in-depth understanding of the operation of youth groups and how financial management can influence any groups financial performance, his hobby is reading and playing chess currently he is involved in training Small scale traders at Langas on proper saving and how to quantitatively and qualitatively measure business long term growth, he is equally a part time lecturer at Kisii University Eldoret Campus

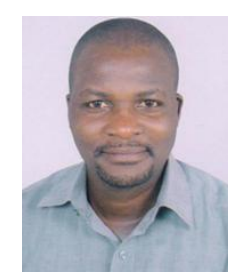

Dr. Gedion A. Omwono, holds bachelor of Commerce from Dr. Bhim Rao Ambedkar formerly, Agra University and MBA from Indian Institute of Business Management and Studies Mumbai and Doctorate in management studies formerly a lecturer at the Catholic University of Eastern Africa, Jomo Kenyatta University of Agriculture and Technology and Eldoret University. Currently he is a lecture at L'A CADEMIE ARABE POUR LA SCIENCE DE FINANCEMENT ET BANCAIRE. 